\title{
Features of Formation of Students Foreign Language Competence in Self-Learning Activity
}

\author{
Alfiya Minnemukhtarovna Ishmuradova ${ }^{1}$, Irina Ilyinichna Leyfa ${ }^{2}$, Gulzida Farshatovna Magadieva ${ }^{1}$, Lyubov \\ Pavlovna Yatsevich ${ }^{2}$, Marina Alexandrovna Demyanenko ${ }^{2} \&$ Regina Borisovna Khismatullina $^{1}$ \\ ${ }^{1}$ Kazan Federal University, Russia \\ ${ }^{2}$ Amur State University, Russia \\ Correspondence: Alfiya M. Ishmuradova, Kazan Federal University, Naberezhnye Chelny, Suumbike av., 10A, \\ Tatarstan, 423812, Russia. E-mail: alfiaishmuradova@mail.ru
}

Received: September 28, 2014 Accepted: December 8, 2014 Online Published: December 30, 2014

doi:10.5539/ass.v11n7p176 URL: http://dx.doi.org/10.5539/ass.v11n7p176

\begin{abstract}
This article is aimed to identify characteristics of the formation of students foreign language skills in the process of self-learning activity. It is proved that foreign language competences are formed as a complex of integrated steady students education as subjects of self-learning activity including: language, speech, compensatory, educational and informative, socio-cultural, communicative and projecting competences. The article submissions are of practical value to foreign language teachers in the organization and planning of students educational and self-learning activity aimed to establish and improve their foreign language competence.
\end{abstract}

Keywords: foreign language competence, self-learning activity, "Foreign Language" discipline, students

\section{Introduction}

In scientific literature there is a differentiation of competencies, such as: professional, core, communicative, language, foreign language, and other. However, the term of "foreign language competence" has not been fixed in scientific literature yet. The gist, content and conditions of formation of students foreign language competence in technical university is developed insufficiently. In particular, it concerns the questions of formation of foreign language competencies through students self-learning activity in the process of learning foreign language. Moreover, the foreign language competences of students in technical university forming on the basis of self-learning activity are discussed in the structure of various competencies (Khairullina, 2007). For exsample, in the works of I. L. Bim (2005), I.A. Zimnyaya (2002), F.M. Kadyrova (2008), E.I. Passov (2007), N. A. Katchalov (2013), A. M. Ishmuradova (2008), A. R. Masalimova, G. D. Ikramova, A. R. Shaidullina, G. T. Gubaidullina, N. D. Apraksina (2014), I. V. Bimurzina (2013) and other communicative competence is considered as a kind of foreign language or language competence. At the same time, the term of "language competence" was used in the structure of communicative competence. Thus the level of development of students foreign language competence in technical university allows us to give a qualitative assessment of communicative, subjective behavior of students in self-learning activity. Competence-based approach in foreign language teaching of technical university students on the basis of self-learning activity is considered to improve the quality of professional higher education aimed on the complex formation of foreign language competencies which are a part of universal competences.

\section{Materials and Methods}

\subsection{Research Methods}

During the study of this problem we used the following methods: theoretical (analysis of psycho-pedagogical and scientific-methodological literature on the research topic, generalization); empirical (analysis of pedagogical situations, training program documentation, study and synthesis of teaching experience on the research, pedagogical supervision of teachers and students, methods of survey, questionnaire, conversations, interviewing, participant observation, testing, projecting); pedagogical experiment (stating, forming and control stages of experiment); statistical processing methods of the quantitative results of study, expert assesment, self-esteem. 


\subsection{Experimental Base and Stages}

An experimental base of research was Naberezhnye Chelny branch of Kazan Federal University.

The research was carried out in three stages:

On the first stage the state of the problem was examined; analysed psycho-pedagogical literature relevant to the research problem; defined the content of students foreign language competence of technical university, tasks, program and methodology of research.

On the second stage experimental work was carried out: collecting the actual material was organized, the assessment and the analysis of skilled experimental data in dynamics were carried out; methodological recommendations on the formation of students foreign language competence of technical university in self-learning activity were developed; training manual "Self-learning activity of technical university students in English language classes" was prepared.

On the third stage the results of research were analyzed, summarized, and discussed; quantitative and qualitative processing was conducted; theoretical interpretation of the findings and provisions of research were carried out ; specific methodological recommendations on the formation of students foreign language competence of technical university in self-learning activity in the process of mastering the "Foreign language" subject were concretized; the effectiveness of formation of students foreign language competence of technical university in self-learning activity was identified.

\section{Results and Discussions}

In the process of theory and practice analysis of psycho-pedagogical literature different perspectives on the role of self-learning activity in learning foreign language by students of technical university were explored. They helped to determine the overall sense of self-learning activity as the program of active, creative, independent students participation in different directions, self-learning sessions; self-study; self-control; self-education. The result of students self-learning activity at study foreign language in technical university was course and degree project.

Experimental work consisted of ascertaining, search, creative (formative) and control stages. The following diagnostic tools were used in ascertaining step: the author's technique to identify the level of formation of various foreign language skills of students in technical university on the basis of the technological card of introspection and manifestation of various abilities of foreign language activity; participant observation of foreign language teachers in the process of self-learning activity of students; test card of self-learning activity of students in foreign language study; a modified version of the questionnaire of individual style in students self-learning activity of technical university in foreign language study.

The level assessment of formation of foreign language competence in self-learning activity was carried out on the basis of students self-esteem and teachers monitoring. These diagnostics were processed by calculation of number of foreign language competences which students defined at themselves and supplemented with expert data. Then correlated or integrated index of development of foreign language competence as average value of all competences was calculated. On ascertaining stage of the experiment starting level of development of students foreign language skills of technical university in self-learning activity was detected. As criteria for students self-learning activity in study foreign language in technical university was defined: student's ability to plan foreign language self-learning activity, to organize and evaluate it; the quantity and quality of independent tasks during the work on educational tasks; readiness for self-use of foreign language competence of students in the process of self-learning activity in foreign language study; students ' attitude toward foreign language activity (the presence of cognitive interest and activity in the selection of types, shapes of self-learning activity).

On the basis of synthesis of manifestation in the course of self-learning activity in foreign language study of various foreign-language competences in the ratio with their criteria indicators, three levels characteristics of their formation were defined.

High level presumes the presence of students ability to plan, carry out and correct foreign self-learning activity on the basis of development of the whole complex of foreign language competence: speech, language, compensatory, educational, socio-cultural, communicative projecting. Students implement self-learning activity in full, using the whole complex of foreign language competencies. Students demonstrate conscious interest to foreign language study on the basis of self-learning activity taking into account specifics of Faculty. Students self-organize study activities in situations of foreign languages communication with specific areas of training in technical university. Students are able to make unconventional decisions, show originality of thinking in a foreign language. Foreign language self-learning activity of students is an active, creative, cognitive character. 
Students have increased motivation for foreign language self-study. Students are able to self work with educational literature, tables, and they strive to improve all foreign language competence on the basis of self work with any source of information in a foreign language. Students make all independent tasks at high qualitative and quantitative levels. Students actively and effectively participate in student conferences, competitions, grants. Students with high level foreign language competencies are successfully meeting course and diploma projects in foreign language. Students are adequately assess the expression of foreign language competencies, revise and develop self-learning activity in study foreign language taking into account the specifics of the technical university.

The average level involves episodic manifestation of students ability to plan self-learning foreign language activity. The majority of students among foreign language competences have only compensatory on a high level, and the educational-cognitive and communicative project competencies are on the average level. Self-learning activity of students is responsive, situational. Doing the individual works in a foreign language, students carry out the transfer of knowledge only within the same module. It is observed the students unconscious motivation to learn a foreign language. Students work with the educational literature, tables only with the help of the teacher. Students show little interest in the process of formation of foreign language competence in self-learning activity. Students occasionally participate in student's conferences, competitions, fundraising activity. Students complete coursework and degree projects only with the systematic control of the teacher. Self-assessment of foreign language competencies, being formed at students of technical university in self-learning activity, appears at high or low levels.

Low level involves students extremely rare desire for self-learning activities. They do not know how to plan and organize self-learning activity. Among the complex of foreign language competencies only speech and language skills are manifested at an average level, others are at low levels. Foreign self-learning activity of students has passive and copying nature. Students show low motivation to study foreign language. Students may not be able to work with textbooks, tables, do not show interest in the process of formation of foreign language competence in self-learning activity. Students occasionally participate in student's conferences, competitions, grants. Self-esteem of formation of the foreign students of the technical University on the basis of self-learning activities is underestimated (Ishmuradova, 2006).

At a search and creative (forming) stage in experimental group in a certain didactic sequence: creation was carried out training of students in algorithm of self-learning activity in foreign language study; trainings on development of foreign-language competences on the basis of use of various forms of self-learning activity were provided; elective courses. Development and learning by the students of technical universities algorithm of self-learning activity were carried out in the process of foreign language study among students of the experimental groups. In the process of self-learning activity of students of technical university various foreign language competences were shown and formed. In the initial stages of the experiment, the foreign language teachers analyzed and diagnosed manifestation levels of foreign language competence in students self-learning activity. In process of mastering algorithm of self-learning activity students independently diagnosed their manifestation. At this stage in educational process the elective course "The Formation of Foreign-language Competences of Self-learning Activity" was used. The program of a special course provided a combination of theoretical and practical project and modular training in foreign language through the use of various forms and types of self-learning activity. In the process of foreign language study on the basis of self-learning activity subjective involvement of students in this process was considered. In foreign language classes in experimental groups both classroom and extracurricular forms of students self-learning activity were in the spotlight . All tasks for independent work of students in foreign language study were built with a specifics of the faculty of technical university. Students self-learning activity of technical university in foreign language study was aimed at both improving and self-esteem level of formation of foreign language competence, promoting the formation of its self-esteem. Professional orientation of students self-learning activity of technical university in the foreign language classroom is an awareness of the opportunities for further use of foreign language competence in the future professional activity. Particular attention was paid to the independence of students in learning activities as the main source of foreign language skills. Self-learning activity in foreign language classes of technical university has been used in different contexts of professional work and personal needs. The result of this work is the experimental group students realization that they need not only quantitative but also qualitative implementation of self-learning activity in foreign language study as an important term in the formation of a competent professional. The development and testing of educational-methodical manual "Students self-learning activity of technical university in English classes." was the completion and the creative phase of the search. The course provided the combination of theoretical and practice-oriented direction of students self-learning activity 
of technical university. This course contributed to the formation of foreign language competence of students of technical university in foreign language study when activated complex of foreign language competencies, changing conditions of self-learning activity.

In the control phase of the experiment 130 students participated. In the experimental group - 64 first-year students, in the control group - 66 people. Experimental and control groups were chosen so that the level of development of students foreign language skills (in the polls, interviews, questionnaires and testing) were approximately the same. Monitoring of formation of foreign language competence was based on the observation of self-observation in the course of self-educational activity of students to perform a variety of tasks. All tasks to identify the initial level of formation of complex foreign language competence of university students have been tested for validity and reliability. The number of students in the control and experimental groups did not differ. Thus, manifestation at students of "average" and "low" levels of foreign-language competences prevailed.

During the stage of the experimental work was carried out comparing the level of forming of foreign language competencies of students of the control and experimental groups of technical university. The experimental results showed that students who study foreign language on the basis of self-learning activity showed interest to the formation of complex foreign-language competencies. Formation of foreign language competencies of the students of technical university in the experimental groups were due to the degree of their self-learning in the process and consideration of the specific areas of training. In the experimental groups in the process of learning foreign language through self-learning activities of students used its various forms and types. Students themselves selected the different forms and types of self-learning activities. In the process of study of foreign language students creatively used different algorithms of self-learning activities. As a result of the experimental work the majority of the students in the experimental group was formed by the need for active, creative learning foreign language based on self- learning activities. All the results of the experimental work are presented in the tables 1 and 2.

Table 1. The ratio of foreign language competencies and criteria indicators formed in students self-learning activity of technical university

\begin{tabular}{cl}
$\begin{array}{c}\text { Foreign language } \\
\text { competencies }\end{array}$ & Indicators \\
$\begin{array}{c}\text { 1. Speech } \\
\text { competences }\end{array}$ & $\begin{array}{l}\text { communicative skills in the four basic skills (speaking, listening, reading, writing) } \\
\text { the ability to understand authentic foreign language texts } \\
\text { the ability to plan verbal and nonverbal behavior with specific communication }\end{array}$ \\
\hline $\begin{array}{c}\text { 2. Language } \\
\text { competences }\end{array}$ & $\begin{array}{l}\text { the ability to learn new language features in accordance with the communication } \\
\text { expressing thoughts } \\
\text { the ability to increase the amount of knowledge due to terminology }\end{array}$ \\
\hline $\begin{array}{c}\text { 3. Compensatory } \\
\text { competences }\end{array}$ & $\begin{array}{l}\text { the ability to find a way out in conditions of deficiency of language means } \\
\text { the ability to compensate insufficiently developed skills to think in a foreign language } \\
\text { due to advanced speech skills } \\
\text { the ability to compensate shortcomings of oral written speech }\end{array}$ \\
\hline $\begin{array}{c}\text { 4. Educational and } \\
\text { informative } \\
\text { competences }\end{array}$ & $\begin{array}{l}\text { the ability to improve educational activities for acquisition of a foreign language } \\
\text { the ability to use the target language in order to continue education } \\
\text { methods of self-study foreign language }\end{array}$ \\
\hline $\begin{array}{c}\text { 5. Socio-cultural } \\
\text { competences }\end{array}$ & $\begin{array}{l}\text { the ability to increase the knowledge about the target language country } \\
\text { the ability to build a speech behavior considering the core-oriented communication } \\
\text { the ability to learn the culture and traditions of the country of studied language }\end{array}$ \\
\hline $\begin{array}{c}\text { 6. Communicative } \\
\text { and project } \\
\text { competences }\end{array}$ & $\begin{array}{l}\text { the ability to make decisions } \\
\text { the ability to define the objectives of the work } \\
\text { the ability to evaluate and adjust the plans in a foreign language }\end{array}$ \\
\hline
\end{tabular}


Table 2. Dynamics of formation of levels of foreign language competences of students of technical university in self-learning activities EG and CG in the course of the experiment (in\%)

\begin{tabular}{|c|c|c|c|c|c|c|c|}
\hline \multirow{3}{*}{$\begin{array}{c}\text { Foreign language } \\
\text { competencies (FLC) }\end{array}$} & \multirow{3}{*}{ Group } & \multicolumn{6}{|c|}{ Levels } \\
\hline & & \multicolumn{2}{|c|}{ Low } & \multicolumn{2}{|c|}{ Medium } & \multicolumn{2}{|c|}{ High } \\
\hline & & $\begin{array}{l}\text { Before } \\
\text { Ex }\end{array}$ & After Ex & $\begin{array}{l}\text { Before } \\
\text { Ex }\end{array}$ & After Ex & $\begin{array}{l}\text { Before } \\
\text { Ex }\end{array}$ & After Ex \\
\hline \multirow{2}{*}{ Speech competencies } & EG & 71 & 44 & 21 & 37 & 8 & 19 \\
\hline & $\mathrm{CG}$ & 70 & 55 & 23 & 33 & 7 & 12 \\
\hline \multirow{2}{*}{ Language competencies } & EG & 66 & 19 & 25 & 53 & 9 & 28 \\
\hline & $\mathrm{CG}$ & 78 & 48 & 12 & 31 & 10 & 21 \\
\hline \multirow{2}{*}{ Compensatory competencies } & EG & 74 & 44 & 20 & 35 & 6 & 21 \\
\hline & $\mathrm{CG}$ & 66 & 48 & 28 & 32 & 6 & 20 \\
\hline \multirow{2}{*}{$\begin{array}{l}\text { Learning-cognitive } \\
\text { competencies }\end{array}$} & EG & 60 & 12 & 28 & 64 & 12 & 24 \\
\hline & $\mathrm{CG}$ & 72 & 35 & 26 & 59 & 2 & 6 \\
\hline \multirow{2}{*}{ Socio-cultural competencies } & EG & 67 & 37 & 29 & 45 & 4 & 18 \\
\hline & $\mathrm{CG}$ & 84 & 61 & 15 & 30 & 1 & 9 \\
\hline \multirow{2}{*}{$\begin{array}{c}\text { Communicative-designing } \\
\text { competencies }\end{array}$} & EG & 74 & 53 & 26 & 36 & 0 & 11 \\
\hline & $\mathrm{CG}$ & 72 & 64 & 28 & 32 & 0 & 4 \\
\hline \multirow{2}{*}{ Integrative criterion of FLC } & EG & 68,6 & 34,8 & 24,8 & 45 & 6,5 & 20,1 \\
\hline & $\mathrm{CG}$ & 73,6 & 51,8 & 22 & 36,1 & 4,3 & 12 \\
\hline
\end{tabular}

In the control group the value of statistical criterion is less than the table. Therefore, we can conclude about the positive results of experimental work on the formation of foreign-language competencies of students of technical university in self-learning activities.

\section{Conclusion}

The process of formation of students foreign language competence of technical university successfully implemented in self-learning activity. It is the term and the result of this process. The content of students foreign language competence of technical university is a complex stable formations of the subject of self-learning activity, including language, speech, compensatory, educational, social, cultural and communicative projecting competences.

The efficiency of the process of formation of the complex of students foreign language competence of technical university in self-learning activity is achieved with a systematic diagnosis, promotion, evaluation and correction.

Developed and implemented in the educational process of educational-methodical manual " students self-learning activity of technical university classes in English language" is one of the main tools to increase the level of development of foreign language competence of technical university students of self-learning activity in foreign language study of technical University with specific areas of training.

\section{References}

Bim, I. L. (2005). Modernization of the structure and content of language education. Foreign languages at school, 8, 2-6.

Bimurzina, I. V. (2013). Russian as a foreign language in a professional context: Study manual (p. 157). Vladivostok, Dalrybvtuz.

Ishmuradova, A. M. (2006). Learning foreign languages in technical universities from the perspective of modernization of education. Socio-economic and technical systems: Research, design, optimization, 12, 12. 
Ishmuradova, A. M. (2008). Formation of foreign language competence of students of technical high school in the project activities. Dissertation for the degree of candidate of pedagogical sciences. Kazan: Institute of Pedagogy and Psychology of Professional Education of the Russian Academy of Education.

Kadyrova, F. M. (2008). Improving the quality of language training for students in a changing labor market. Kazan Pedagogical journal, 8, 32-38.

Katchalov, N. A. (2013). Exersise sets and their methodological organization in developing practical skills. Tomsk State Pedagogical University Bulletin, 7, 143-147.

Khairullina, E. R. (2007). Orientation of students to self-development of core competencies in the design and creative activity. Science and Education Journal, 7.

Masalimova, A. R., Ikramova G. D., Shaidullina, A. R., Gubaidullina, G. T., \& Apraksina, N. D. (2014). Distant in-company foreign language learning involving university student-tutors. Am. J. of App. Sci., 11, 1123-1127. http://dx.doi.org/10.3844/ajassp.2014.1123.1127

Passov, E. I. (2007). The concept of communicative foreign language education: A manual for Russian studies (p. 145). Moscow.

Zimnyaya, I. A. (2002). Educational psychology (p. 384). Moscow, Logos.

\section{Copyrights}

Copyright for this article is retained by the author(s), with first publication rights granted to the journal.

This is an open-access article distributed under the terms and conditions of the Creative Commons Attribution license (http://creativecommons.org/licenses/by/3.0/). 